\title{
Story-telling: Upaya Meningkatkan Daya Simak dalam Keterampilan Menyimak Interaktif Berbahasa
}

\author{
Saptono Hadi \\ Program Studi Pendidikan Bahasa Indonesia, Universitas Nahdlatul Ulama Blitar \\ Email: hsaptono77@yahoo.com
}

\section{Tersedia Online di}

http://www.jurnal.unublitar.ac.id/ index.php/briliant

\begin{tabular}{l}
\hline Sejarah Artikel \\
\hline Diterima pada 2 April 2017 \\
Disetuji pada 16 April 2017 \\
Dipublikasikan pada 1 Mei 2017 \\
Hal. 163-177 \\
\hline
\end{tabular}

\section{Kata Kunci:}

Story-telling, daya simak, berbahasa

\begin{abstract}
Abstrak: Keterampilan menyimak merupakan suatu kegiatan berbahasa yang bertujuan menangkap dan memahami lafal, ujaran, intonasi, makna kata-kata atau kelompok kata, kalimat, alinea atau paragraf, untuk mengungkapkan ide/gagasan yang disampaikan. Proses kognitif penyimak menjadi pengaruh kemampuan menyimak dan tidak mungkin dapat diamati secara langsung. Melalui story telling, bercerita, mendongeng baik yang bersifat fiksi maupun nonfiksi sesuai yang diinginkan akan memberikan kemudahan daya simak anak didik dalam mencerna makna dan isi pesan yang dikandungnya. Melalui pemahaman kegiatan berbicara melalui dongeng dengan menekankan menyimak akan terjadi akulturasi pola sikap dan tingkah laku siswa didik.
\end{abstract}

Pelaksanaan kegiatan belajar-mengajar khususnya pengajaran Bahasa Indonesia yang dilakukan oleh pendidik pada keterampilan menyimak, terfokus (1) proses belajar mengajar masih berpusat pada guru (Teacher Center Learning) sehingga siswa kurang aktif menemukan konsep, (2) terdapatnya ketidakpedulian seorang guru karena kesibukan tugas tambahan atau bentuk lain sehingga tidak mempedulikan apakah siswa mengikuti pembelajaran atau tidak, (3) ketidakmampuan guru memahami karakter siswa sehingga terjadi kesenjangan karena penjelasan guru sulit atau tidak mampu dipahami anak, (4) siswa sibuk sendiri dengan mainannya dan tidak konsentrasi terhadap pembelajaran, (5) tidak terdapatnya interaksi ketika guru memberikan pertanyaan-pertanyaan karena siswa tidak atau belum menguasai materi, (6) ketidakantusiasnya siswa mengikuti kegiatan belajar-mengajar, (7) adanya tindakan guru yang mengabaikan pemerolehan pengetahuan atau kemampuan siswa yang dimiliki sebelumnya, (8) terdapatnya simpulan bahwa hanya ada 6-9 siswa saja yang tuntas belajarnya karena nilai di atas KKM yang ditentukan, sedang lainnya di bawah KKM. Hasilnya, dapat dinyatakan bahwa kegagalan pembelajaran terjadi karena guru dan siswa tidak memahami atau guru belum mampu memberikan pemahaman pentingnya daya simak pada kajian keterampilan menyimak sebagai landasan mendasar pada peningkatan belajar.

Dimyati (2009:33) mendeskripsikan bahwa di antara motivasi belajar siswa ada yang dapat diperkuat dengan cara pembelajaran. Motivasi instrumental, motivasi sosial, dan motivasi berprestasi rendah misalnya dapat dikondisikan secara bersyarat agar terjadi peran belajar siswa. Adapun acara-acara pembelajaran yang berpengaruh pada proses belajar dapat ditentukan oleh 
pendidik. Kondisi eksternal yang berpengaruh pada proses belajar adalah bahan belajar, suasana belajar, media, teknik pembelajaran, media pembelajaran, dan subjek pembelajar (pendidik) itu sendiri. Lebih lanjut Dimyati, belajar yang terjadi pada individu merupakan perilaku yang sangat kompleks, tindak interaksi antara pebelajar dan pembelajar yang bertujuan. Oleh karena berupa akibat interaksi, maka belajar dapat didinamiskan antara pelaku belajar dan lingkungan pebelajar.

Dinamika pebelajar yang bersifat internal, terkait dengan peningkatan hierarki ranah kognitif, afektif, maupun psikomotorik dan kesemuanya terkait dengan tujuan pembelajaran. Sedangkan dinamisasi dari luar (eksternal) dapat berasal dari guru atau pendidik. Pendinamisasian belajar tersebut berkenaan dengan kesiapan siswa/anak didik menghadapi bahan ajar, penciptaan suasana belajar yang menyenangkan, optimalisasi media, sumber belajar, dan memaksimalkan peran sebagai pembelajar. Kegiatan pembelajaran dimaksudkan agar tercipta kondisi yang memungkinkan terjadinya belajar pada diri siswa. Dalam suatu kegiatan pembelajaran dapat dikatakan terjadi belajar. Dikatakan belajar jika terjadi proses perubahan perilaku pada diri siswa/anak didik sebagai hasil dari suatu pengalaman. Dua aspek penting yang ada dalam kegiatan pembelajaran, yakni aspek pertama berkaitan dengan aspek hasil belajar yang berupa perubahan tingkah laku, dan aspek kedua berkaitan dengan aspek proses belajar yang berupa sejumlah pengalaman intelektual, emosional, dan fisik pada diri anak didik.

Sampai saat ini para pakar pendidikan berpendapat bahwa pengaruh keterbelakangan pendidikan di Indonesia adalah dalam hal pembelajaran. Pembelajaran cenderung terpusat pada pendidik (Teacher Center Learning), dan siswa hanya sekedar dianggap sebagai unsur pelengkap. Akhirnya pembelajaran, apa yang dirasakan, diresahkan dan diinginkan siswa, sama sekali belum menjadi pertimbangan pendidik. Dan guru cenderung terbiasa 'asyik' dengan deretan materi pelajaran yang telah disiapkan sesuai dengan seleranya. Dalam pandangan guru, rancangan yang dituangkan dalam skenario pembelajaran atau rencana pelaksanaan pembelajaran (RPP) harus terlaksana. Ternyata fakta yang didapat berbeda; sering kenyataan dilapangan tidak sejalan dengan skenario yang ada, terutama pada perilaku siswa. Mendapatkan realitas seperti di atas, anehnya guru tidak merasa bersalah, namun justru siswa menjadi 'kambing hitam'. Akibatnya dalam praktik belajar, siswa sering merasa bersalah, tertekan, hilang rasa percaya diri dan lebih banyak menunggu.

Dalam kondisi seperti di atas, pembelajaran banyak diwarnai pemaksaanpemaksaan sehingga siswa tak ubahnya barang dan benda kosong yang dapat diisi dan dikondisikan sesuai dengan keinginan guru. Ketidaksesuaian realitas dengan skenario biasanya dianggap guru sebagai sebuah kesalahan fatal, dan harus segera dipaksa sebagaimana yang telah direncanakan. Di sinilah barangkali awal dari kesalahan, dan siswa pun terpaksa meng-iya-kan dan melakukan apa yang diinginkan guru. Keterpaksaan siswa yang berlangsung akan memunculkan rasa takut, serta kehilangan rasa percaya diri, bahkan mereka merasa tidak lagi dicintai, dan pada gilirannya akan menyebabkan hilangnya motivasi belajar siswa. Kondisi seperti itu menyebabkan hilangnya motivasi belajar untuk mencapai perkembangan keterampilan berbahasa. Keterpaksaan siswa yang berlangsung terus-menerus akan memunculkan rasa takut, kehilangan rasa percaya diri, bahkan

164 BRILLIANT: Jurnal Riset dan Konseptual Volume 2 Nomor 2, Mei 2017 
mereka merasa tidak lagi dicintai, dan pada gilirannya akan menyebabkan hilangnya motivasi belajar siswa, memunculkan sikap siswa yang berpura-pura, senang main curang, menipu, menyontek, mencuri, saling jegal satu sama lain dan sebagainya. Bentuk lain, motivasi mempunyai kaitan erat dengan minat. Siswa yang memiliki minat terhadap sesuatu bidang studi cenderung tertarik perhatiannya dan dengan demikian timbul motivasinya untuk mempelajari bidang studi tersebut. Karenanya, bahan-bahan ajar yang disajikan hendaknya disesuaikan dengan minat anak didik dan tidak bertentangan dengan nilai-nilai yang berlaku dalam masyarakat (Dimyati, 2009: 43).

Menurut Hamalik (2013:24) pembelajaran terkait dengan tujuan dan rencana kurikulum, yang difokuskan pada persoalan metodologi, seperti teknik mengajar, kegiatan implementasi sumber, dan alat pengukuran yang digunakan dalam situasi mengajar-belajar yang khusus. Dan proses belajar-mengajar merupakan dua peristiwa yang berbeda, tetapi keduanya memiliki hubungan yang erat, bahkan terjadi kaitan dan interaksi yang saling mempengaruhi dan menunjang satu sama yang lain.

Dongeng adalah paparan rekaan tentang kejadian atau aktifitas yang berhubungan dengan suatu tokoh dalam konteks tertentu. Rangkaian alur cerita dalam dongeng ini secara keseluruhan merupakan suatu kejadian berkarakter yang membentuk keutuhan dan penciptaan karya sastra bentuk dongeng ini dimaksudkan untuk menghibur, mendidik, dan wahana ajaran moral yang mengena. Sifat kayal yang terbentuk dan koherensi pada dongeng ini memberikan kekuatan magis yang mudah mempengaruhi perilaku anak didik. Bentuk lain, dongeng berciri mudah dicerna, dengan gaya bahasa sederhana akan memudakan bagi anak didik memberikan respon terhadap gambaran, rangkaian atas makna pesan yang dimunculkan dalam dongeng.

Kurikulum mata pelajaran Bahasa Indonesia menyatakan fungsi utama bahasa adalah untuk berkomunikasi. Jelas, mengacu pada pendapat tersebut, keterampilan berbahasa sangatlah diutamakan. Komunikasi di sini sebagai proses menyampaikan maksud, gagasan, ide, keinginan, informasi baik ilmiah maupun non ilmiah. Dapat dibayangkan bagaimana jika kemampuan keterampilan berbahasa itu tidak dimiliki oleh seseorang. Sudah barang tentu keterampilan menyimak sebagai keterampilan pertama untuk mendapatkan informasi akan terhambat, sehingga informasi yang diinginkan atau ingin disampaikan tidak akan mencapai sasaran atau terhambat. Sebagai program pendidikan yang telah direncanakan secara sistematis, kurikulum mengemban peranan yang sangat penting bagi pendidikan siswa. Apabila dianalisis sifat dari masyarakat dan kebudayaan, dengan sekolah sebagai institusi sosial dalam melaksanakan operasinya, maka dapat ditentukan paling tidak tiga peranan kurikulum yang sangat penting, yakni peranan konservatif, peranan kritis atau evaluatif, dan peranan kreatif. Ketiga peranan ini sama penting dan perlu dilaksanakan secara seimbang (Hamalik, 2013:11). Alexander Inglis mengatakan bahwa kurikulum berfungsi sebagai fungsi penyesuaian, fungsi pengintegrasian, fungsi deferensial, fungsi persiapan, fungsi pemilihan, dan fungsi diagnostik (Hamalik, 2013:77).

Melalui Cerita/dongeng aktifitas mendengarkan, membaca, menggubah, dan menulis akan mampu memberikan kemampuan daya simak/keterampilan anak didik untuk terampil menyusun kejadian-kejadian yang disampaikan berdasarkan kemampuan nalar mereka. Mendengarkan atau menyimak sebuah cerita berarti

165 BRILLIANT: Jurnal Riset dan Konseptual Volume 2 Nomor 2, Mei 2017 
terjadi adanya suatu aktifitas aktif yang berupa kemampuan menangkap dan memahami lafal, ujaran, intonasi, makna kata-kata atau kelompok kata baik secara perkalimat, alinea dalam bentuk wacana cerita yang di dalamnya terdapat idea tau gagasan yang ingin disampaikan. Sehingga, berdasar uraian tersebut jelas melalui cerita bentuk dongeng ini, anak didik akan mudah terbawa ke dalam medan cerita yang diungkapkan. Proses berikutnya, dengan berbekal emosi, intelegensi, dan daya imajinasi yang dimiliki, anak akan mudah memberikan tanggapan atau respon positif. Akhirnya, anak akan dengan mudah mendapatkan pemerolehan pembelajaran, dan daya simak anak terhadap materi yang diajarkan semaikin meningkat.

Permasalahan penting yang muncul dan dihadapi adalah rendahnya kemampuan keterampilan menyimak siswa. Di mana dalam proses kegiatan belajar-mengajar sering terjadi suatu keadaan bahwa siswa didik mengalami ketidaksemangatan dalam mengikuti pembelajaran. Di lain sisi kegiatan menyimak yang menjadi kebiasaan dinyatakan sebagai proses menjenuhkan dan melelahkan. Bentuk lain dari faktor dari pendidik (guru) tidak memahami bahwa kegiatan menyimak (mendengarkan) adalah keterampilan yang sangat penting bagi pertumbuhan kemampuan dan keterampilan berbahasa, sebagai keterampilan dasar yang harus dipahami anak didik dalam mempelajari atau mengkaji materi ajar dalam pembelajaran. Penulis berpendapat bahwa pertumbuhan kemampuan dan keterampilan seseorang berbahasa dimulai dari menyimak (mendengarkan), kemudian berbicara, membaca, dan menulis. Sehingga ketidaksemangatan yang tercermin pada ekspresi dan tingkah laku anak didik dengan (daya simak) memainkan kegiatan lain pada proses KBM sudah dapat dikatakan pada prestasi hasil belajar siswa pada materi keterampilan menyimak itu rendah. Meskipun dikatakan demikian, pendidik tampaknya tidak terdapat sikap ketertarikan untuk melakukan pengkajian pada kegiatan menyimak ini, apalagi mengadakan pengembangan keterampilan berbahasa pada anak tersebut. Berdasarkan pada sikap dan problematik itu, banyak hal yang perlu dianalisis dalam usaha memaksimalkan pemerolehan anak dalam keterampilan berbahasa melalui kegiatan mendongeng (story-telling) untuk meningkatkan kemampuan daya simak anak dalam menyimak materi.

Belajar-mengajar merupakan kegiatan yang mengaktifkan siswa dalam membangun makna atau pemahaman. Namun dalam pemikiran praktisi pendidikan, makna dan hakikat belajar sering kali hanya diartikan sebagai penerima informasi dari sumber informasi (pendidik dan buku bahan ajar). Akibatnya kebanyakan guru dalam kegiatan belajar mengajar masih sebagai sarana tokoh transfer informasi kepada siswa yang mengakibatkan anak didik menjadi malas belajar dan cenderung pasif pada kegiatan belajar-mengajar. Inti sebenarnya bahwa dalam tujuan pembelajaran siswa diwajibkan aktif, kreatif, mandiri, terampil dalam memecahkan masalah maupun dalam mengambil keputusan, percaya diri, serta siswa diharapkan ada kemampuan bersosialisasi dengan teman-temannya.

Pada pelajaran sastra, umumnya siswa diajarkan untuk menganalisis unsur-unsur yang membangun karya sastra baik instrinsik maupun ekstrinsik, menulis karya sastra dengan menggunakan daya pikirnya sendiri, bermain peran, dan lain-lain. Hal ini disebabkan, sastra merupakan sebuah karangan imajinatif atau karya sastra yang bersifat khayalan yang mengungkapkan pengalaman hidup

166 BRILLIANT: Jurnal Riset dan Konseptual Volume 2 Nomor 2, Mei 2017 
manusia secara sungguh-sungguh dan menyentuh dengan menggunakan medium bahasa yang indah menarik, memberikan kemanfaatan sastra yang mendalam bagi anak didik dalam kehidupannya, terutama karakter pembelajaran yang diberikan.

Berdasarkan analisis di atas, maka perlulah kiranya pendidik berusaha membangun sebuah kemampuan keterampilan berbahasa yang difokuskan pada keterampilan menyimak interaktif sebagai pembelajaran meningkatkan kemampua daya simak anak didik melalui suatu kegiatan mendongeng (story-telling). Menyimak pada dasarnya merupakan suatu keterampilan lisan yang bersifat resesif, terjadi secara tatap muka, dan mendengar merupakan komponen integral dalam menyimak yang di dalamnya terdapat proses berfikir, mengidentifikasi, menyeleksi atau menangkap rentetan bunyi bahasa yang bermakna. Dengan dongeng yang sesuai dengan ranah anak didik yang disampaikan dengan baik akan memeberikan makna yang baik.Di luar kemanfaatan kebahasan, sebuah cerita yang bagus sesuai dengan tingkat anak didik akan memberikan dampat yang positif bagi pemerolehan pembelajaran dan tindak didik bagi anak. Apalagi jika pendidik mampu melakukan tindakan kelas dengan proses kebahasaan yang baik dan kondusif, sudah tentu akan terjadi proses interaksi positif anak didik. Melalui story-telling (mendongeng), diharapkan dapat meningkatkan daya simak siswa atau anak didik. Semoga artikel ini bermanfaat untuk menambah pengetahuan dan pengembangan keterampilan menyimak interaktif melalui sebuah media story-telling (mendongeng) dalam upaya meningkatkan daya simak anak didik dan dapat dijadikan salah satu solusi peningkatan pembelajaran.

\section{PEMBAHASAN}

\section{Belajar, Perkembangan, dan Pendidikan}

Menurut Dimyati (2009:7) belajar, perkembangan, dan pendidikan merupakan hal yang menarik. Ketiga gejala tersebut terkait dengan pembelajaran. Belajar dilakukan oleh siswa/anak didik secara individu. Perkembangan dialami dan dihayati oleh anak didik, sedangkan pendidikan merupakan kegiatan interaksi yang dirumuskan pendidik bertindak mendidik anak didik yang bertujuan pada perkembangan kemandirian anak didik. Untuk melangkah pada sifat ini maka anak didik harus belajar, sehingga terjadi perubahan baik pada ranah kognitif, afektif, maupun psikomotorik. Sedangkan Skinner dalam) berpendapat bahwa belajar adalah suatu perilaku. Pada saat orang belajar, maka responsnya menjadi lebih baik. Sebaliknya, bila ia tidak belajar maka responsnya akan menurun (Dimyati, dkk, 2009:9)

Suatu kenyataan bahwa setiap orang dari banyak segi selalu unik dan khas, sehingga sikap dan perilaku yang terjadi seringkali bahasa yang diungkapkan menimbulkan respon kepada otak kita untuk berpikir, pemikiran untuk menerima atau menolak ide, gagasan atas perilaku kepribadian bahasa yang kita terima, terutama dalam ranah psikologi.

Proses lain, bahasa dapat dilihat dari tiga pendekatan, yaitu (1) bahasa sebagai sebuah sistem, (2) bahasa sebagai tingkah laku personal, dan (3) bahasa sebagai tingkah laku antarpersonal. Bahasa dikatakan sebagai sistem bunyi yang arbiter yang dipergunakan oleh anggota kelompok sosial untuk bekerja sama, berkomunikasi dan mengidentifikasikan diri. Nuraeni (2010:63) menyatakan bahwa sebagai sebuah sistem, bahasa mensyaratkan adanya kaidah yang mengatur sistem tertentu yang tidak bersifat statis namun dinamis sehingga dapat 
berkembang sesuai dengan perkembangan penutur bahasa yang dapat terlihat pada tingkah laku personal. Sehingga penggunaan bahasa oleh sesorang dapat dijadikan alat untuk menerka proses ide/gagasan yang terjadi atas seseorang dengan pola perilaku secara psikologis.

Jika kita mendengar orang berbicara, proses komunikasi, sesungguhnya kita mendengar bunyi-bunyi yang tersusun atas kaidah-kaidah bahasa. Menurut Busri (2013:51), menyatakan bahwa dalam proses komunikasi biasanya digunakan berbagai macam unsur materi kebahasaan. Namun demikian tidak semua unsur yang digunakan itu merupakan penentuan proses saling mengerti. Suatu kenyataan bahwa penutur telah memiliki seperangkat pengetahuan tentang ciri pembeda bahasa yang berfungsi sebagai penentu proses saling mengerti dalam komunikasi sehingga ide/gagasan mampu tercerna. Bentuk lain menurut Busri (2013:151) bahasa, tindakan, pengetahuan, dan situasi dalam kenyataannya tidak dapat dipisahkan. Beberapa tindakan hanya dapat dibentuk melalui bahasa, sementara tidakan lain juga dapat dibentuk secara verbal dan non-verbal. Sementara itu, apabila kita mengetahui bagaimana suatu bahasa digunakan dalam interaksi, akan jelas bagi kita bahwa komunikasi dengan menggunakan bahasa tidak akan berlangsung tanpa pengetahuan dan asumsi-asumsi di antara penyapa dan pesapa baik lisan atau tulis. Di samping itu, komunikasi sebagai ranah interaksi dipengaruhi oleh situasi atau keadaan tertentu. Jurnal PGSD UPD (2013:20), Martinis dan Bansu menyatakan bahwa proses pembelajaran dirancang mengikuti prinsip-prinsip belajar-mengajar. Belajar pada hakekatnya merupakan proses perubahan di dalam kepribadian yang berupa kecakapan, sikap, kebiasaan, dan kepandaian. Perubahan ini bersifat menetap dalam tingkah laku yang terjadi sebagai suatu hasil dari latihan atau pengalaman.

Pada pelajaran sastra, umumnya siswa/anak didik diajarkan untuk menganalisis unsur-unsur yang membangun karya sastra dari dalam (instrinsik) maupun dari luar sastra (ekstrinsik). Karya sastra (dongeng) yang bersifat khayal, mengungkapkan pengalaman hidup yang sesuai dengan kebutuhan dan minat anak didik, dan diungkapkan secara sungguh-sungguh serta menyentuh dengan penguasaan bahasa cerita yang bagus, penceritaan menarik tentu akan memberikan daya tarik mendengarkan bahkan akan memberikan efek menyimak lebih efektif. Tarigan menerangkan bahwa pemerolehan bahasa adalah suatu proses yang dipergunakan oleh anak-anak untuk menyesuaikan serangkaian hipotesis yang makin bertambah rumit ataupun teori-teori yang masih terpendam atau tersembunyi yang mungkin sekali terjadi adengan ucapan-ucapan orang tuanya sampai dia memilih berdasarkan suatu ukuran atau takaran penilaian tata bahasa yang paling baik serta yang paling sederhana dari bahasa tersebut (Depdiknas, 2008:16).

Menurut Saryono (2010:78) menerangkan bahwa manusia selaku pembelajar kreatif dalam pembelajaran bahasa, tidak selalu dikondisikan oleh pengetahuan-pengetahuan yang sudah dimiliki dan lingkungannya. Tetapi, adanya proses kreatif akan menyebabkan pembelajar melakukan proses konstruksi kreatif dalam pemerolehan bahasa. Proses kreatif di sini dimaksudkan suatu proses pembentukan sistem kaidah setapak demi setapak pemerolehan berdasarkan ujaran yang didengar atau diserap oleh pembelajar sebagai usaha membentuk berbagai macam hipotesis yang sedang dipelajarinya. Saryono (2010: 1-5) menjelaskan bahwa secara garis besar teori pemerolehan bahasa dikelompokkan

168 BRILLIANT: Jurnal Riset dan Konseptual Volume 2 Nomor 2, Mei 2017 
ke dalam empat rumpun, yaitu rumpun behavioris, rumpun kognitif, rumpun nativis, dan rumpun humanitis.

Model pemerolehan bahasa rumpun behavioristik berpangkal pada psikologi behavioristis sebab pengembangnya para psikolog berpaham behavioristis. Dan secara tidak langsung berpangkal pada filsafat empiris, psikologis behavioris, dan llinguistik struktural Amerika. Menurut pandangan kaum ini, tidak ada unsur linguistik yang dibawa sejak lahir. Anak yang baru lahir dianggap kosong dari bahasa, tidak membawa potensi bahasa. Mereka beranggapan pengetahuan dan keterampilan berbahasa diperoleh melalui pengalaman dan proses belajar, yang membentuk pemerolehan bahasanya. Model pemerolehan bahasa rumpun kognitif berpangkal pada psikologi kognitif dan psikologi Gestalt, yang mana keduanya ini berpangkal pada filsafat rasionalis. TPB ini tidak memiliki akar linguistik yang jelas. Para penganut teori ini beranggapan bahwa struktur serta proses linguistik yang abstrak mendasari produksi dan komperehensi ujaran. Hanya melalui proses kognitif yang terjadi di otak, setiap orang adapat mengatur dan memahami peristiwa-peristiwa nyata yang ada di lingkungannya. Model pemerolehan bahasa rumpun nativis menekankan spekulasi rasionalis tentang proses mental yang dialami oleh pembelajar sewaktu belajar bahasa. Pembelajar sebagai manusia dipandang selalu aktif dan kreatif mengolah masukan-masukan bahasa yang diterimanya. Keaktifan dan kekreatifan ini tidak tergantung pada adanya stimulus yang beasal dari faktor eksternal llingkkungan tetapi karena struktur kejiwaan yang besubstansi demikian (Saryono, 2010:34). Model pemerolehan bahasa rumpun humanistis berpangkal pada sosiolinguistik yang didukung oleh filsafat eksistensial dan fenomenologis yang berlandaskan sosiolinguistik, psikologis humanistis, dan filsafat eksistensial dan fenomenologis.

\section{Keterampilan Berbahasa}

Keterampilan berbahasa secara luas mencakup dua domain utama, yakni kompetensi dan performansi bahasa Indonesia, yaitu kemampuan memahami dan menggunakan bahasa secara baik dan benar dalam kegiatan berkomunikasi baik lisan dan tulis. Kompetensi merupakan domain konseptual berupa pengetahuan siswa tentang aspek teori, prinsip, dan kaidah kebahasaan serta kesastraan dalam bahasa Indonesia (Fajar Arief, 2008:2).

Dalam berkomunikasi kita menggunakan keterampilan berbahasa. Ada anak didik yang memiliki keterampilan berbahasa secara optimal akan memiliki kemampuan daya simak terhadap ujaran atau materi komunikasi sehingga setiap tujuan komunikasinya mudah tercapai. Namun, ada pula orang yang sangat lemah tingkat keterampilannya sehingga bukan tujuan komunikasinya tercapai, tetapi terjadi salah pengertian yang berakibat tujuan terhambat. Dapat dibayangkan bagaimana jika anak didik tidak memiliki kemampuan berbahasa! Sudah barang tentu kita tidak dapat mengekspresikan perasaan dan tidak dapat memahami pikiran, perasaan, gagasan, dan fakta yang disampaikan oleh pembicara.

\section{Meningkatkan Daya Simak Melalui Story-Telling}

Mulyati (2008:1.10), mendengarkan atau menyimak adalah keterampilan memahami bahasa lisan yang bersifat resesif. Dengan demikian, menyimak bukan sekedar mendengarkan bunyi-bunyi bahasa melainkan sekaligus memahaminya. 
Dalam bahasa pertama (bahasa ibu), memperoleh keterampilan mendengarkan melalui proses yang tidak kita sadari betapa kompleknya keterampilan mendengarkan itu. Menyimak atau dalam kurikulum sekolah digunakan istilah mendengarkan, dalam kehidupan sehari-hari merupakan suatu kegiatan berbahasa yang sangat penting. Dengan memiliki pemahaman tentang hakekat keterampilan menyimak, siswa di sekolah dapat menambah ilmu, menerima dan menghargai pendapat orang lain tanpa harus terjadi suatu proses miskomunikasi terhadap idea tau gagasan yang disampaikan. Oleh sebab itu, untuk memperoleh kemampuan menyimak, daya simak, diperlukan latihan-latihan yang intensif. Pada dasarnya pengembangan keterampilan menyimak tingat dasar ini dapat dibedakan atas empat tataran pokok, yaitu (1) tataran identifikasi, (2) tataran identifikasi dan seleksi tanpa retensi, (3) tataran identifikasi dengan seleksi terpimpin dan retensi jangka pendek, (4) tataran identifikasi dengan seleksi retensi jangka panjang (Mulyati, 2008:2.3).

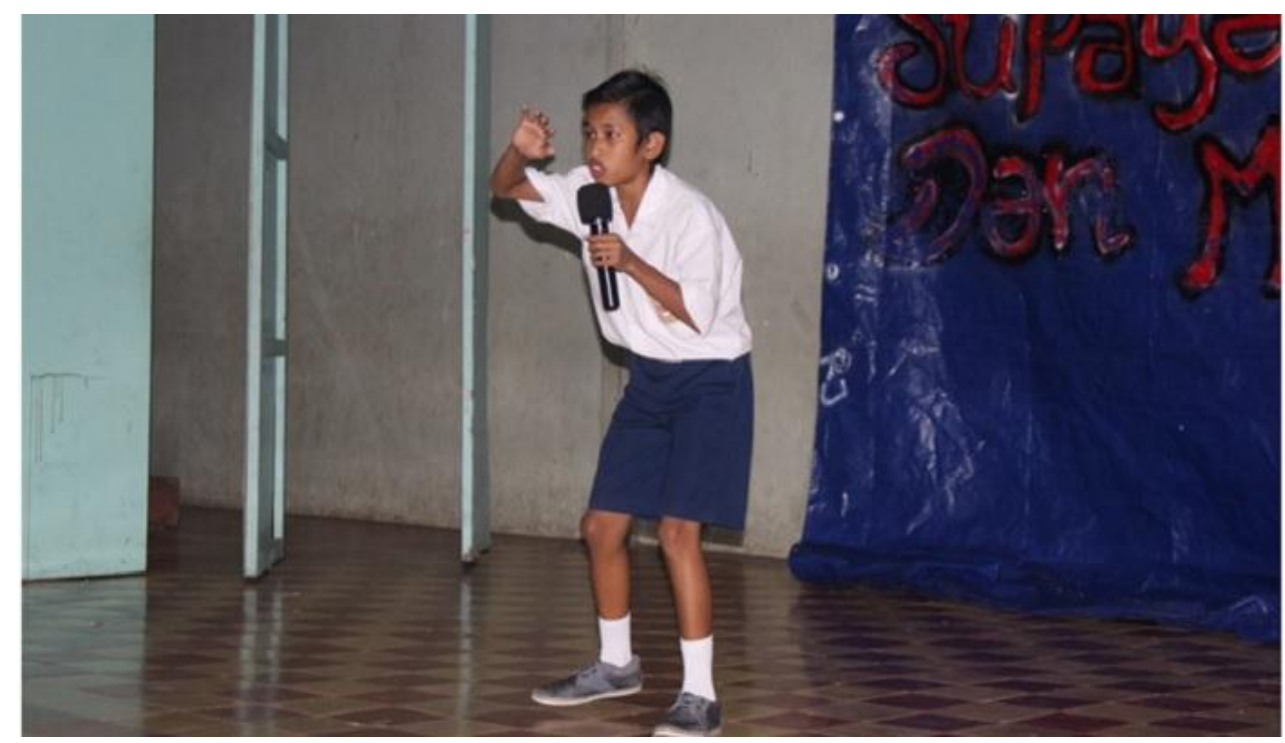

Gambar 1. Story-telling (diambil dari www.google.com)

Menurut Brooks, berbicara dan mendengarkan merupakan kegiatan komunikasi 2 arah yang langsung, komunikasi interaktif. Dan menurut Dawson menjelaskan hubungan antara berbicara dan mendengarkan adalah (1) ujaran biasanya dipelajari melalui mendengarkan dan meniru, (2) ujaran seseorang mencerminkan apemakaian bahasa di lingkungannya, (3) upaya yang dilakukan untuk meningkatkan kemampuan mendengarkan berarti pula membantu meningkatkan kualitas berbicara, (4) bunyi suara yang diden gar merupakan faktor penting yang berpengaruh terhadap kemampuan berbicara, Mulyati (2008: 1.181.19). selanjutnya Faris (1993:154) menguraikan proses menyimak atas 3 tahapan, yaitu (1) menerima masukan auditori, (2) memperhatikan masukan auditori, penyimak berkonsentrasi secarta fisik dan mental, (3) menafsirkan dan berinteraksi dengan masukan auditori. Penyimak tidak sekedar mengumpulkan dan menyimpan pesan tetapi juga mengklasifikasikan, membandingkan, dan menghubungkan pesan dengan pengetahuan, Mulyati (2008:2.4). dan 
Montgomery merinci berbagai penghalang terhadap menyimak aktif sebagai berikut: (1) melamun, (2) mendengarkan fakta saja, (3) sikap badan yang kurang baik, (4) tidak menyimak, (5) emosi, (6) pura-pura memperhatikan, (7) asyik membuat catatan, Depdiknas (2008:34).

Sehingga dikatakan proses menyimak merupakan proses interaktif yang mengubah bahasa lisan menjadi makna dalam pikiran. Dengan demikian, menyimak tidak sekedar mendengarkan. Dan mendengar merupakan komponen integral dalam menyimak. Maka kegiatan berpikir atau menangkap makna dari apa yang didengar merupakan bagian dari proses menyimak dengan berbagai halangan atau penghambat yang perlu diperhatikan dalam membangun kemampuan daya simak anak didik dalam proses kemampuan berbahasa dan menangkap ide atau gagasan dalam berkomunikasi.

\section{Mendongeng}

Mendongeng yang berasal dari kata dongeng merupakan kesusasteraan yang mencakup ekspresi kesusasteraan yang disebarkan dan turun temurun. Dongeng merupakan cerita berkarakteristik khayal yang digunakan karena anakanak lebih gampang mencerna ajaran dalam rangkaian cerita disamping dongeng tersebut memberi konteks yang wajar sebagai sarana ajaran kehidupan. Melalui cerita, anak dapat memp]elajari dan memaknai dunia mereka. Menurut Danandjaja dalam Jurnal UPD (2012:21) dongeng merupakan cerita prosa rakyat yang tak dianggap benar-benar terjadi, dongeng diceritakan terutama untuk memberikan hiburan, walaupun banyak juga melukiskan kebenaran dan berisikan pelajaran moral atau bahkan sindiran.

Dongeng memiliki fungsi yang sangat kompleks bagi kehidupan, dongeng memberikan pesan moral yang sangat bermanfaat baginseseorang terutama anak yang beranjak dewasa untuk membentengi dirinya agar tidak terbawa arus pergaulan yang tidak wajar. Adapun dongeng dalam kehidupan berfungsi (1) sebagai alat lembaga kebudayaan, (2) sebagai alat pendidikan, (3) sebagai kendali masyarakat, (4) sebagai penyampai pesan dan nilai tambah pengetahuan dan pengalaman batin serta membantu proses identifikasi diri dan perbuatan anak. Sehingga melalui kegiatan mendongeng pendengar/pembaca akan berpotensi menstimulus dan mendidik melalui keterlibatan dalam rangkaian alur cerita, kejadian dan pertarungan tokoh yang dimunculkan. Dengan berb ekal emosi, intelegensi dan daya imajinasi, anak akan turut mendalami. Aapalagi dengan didukung sebuah dongeng yang baik, tepat sesuai dengan ranah keinginan dan kesesuaian anak didik.

\section{Keterpaduan Keterampilan Berbicara dengan Fokus Menyimak}

Menyimak dan berbicara memiliki hubungan yang sangat erat karena keduanya merupakan keterampilan yang berada dalam satu ragam bahasa, yaitu bahasa lisan. Proses menyimak dan berbicara dapat dilakukan baik secara tatap muka maupun tidak. Namun dalam proses interaksi bukan non-interaksi, maka mendongeng interaksi berarti terjadi pada situasi tatap muka. Mulyati (2008:6.4) menyatakan bahwa hubungan yang erat antara menyimak dan berbicara seperti berikut: (1) suatu ujaran dapat dipelajari melalui menyimak dan meniru. Aanak akan menyimak ujaran-ujaran orang di sekitarnya dan menirukannya sampai akhirnya dia dapat berbicara, (2) seseorang (anak atau dewasa) akan lebih mudah 
mengulang cerita yang disimaknya dibandingkan dengan cerita yang dibacanya, (3) seorang pembicara yang ucapannya tidak jelas akan mempengaruhi hasil yang diperoleh penyimak.

Proses komunikasi, berbicara secara alamiah selalu terpadu dengan proses menyimak. Tidak ada sesorangpun yang mau berbicara tanpa ada penyimak. Berbicara merupakan sebuah keterampilan menyampaikan gagasan, informasi atau pesan kepada orang lain dengan menggunakan media bahasa lisan. Seorang pembicara akan berusaha melengkapi keterampilannya dengan gestur atau gerak untuk membantu penyimak dalam memahami pembicaraannya. Sehingga dari pola ini, diharapkan melalui kegiatan berbicara melalui dongeng, akan terjadi akulturasi pola sikap dan tingkah laku yang mengalami perubahan daya simak yang lebih baik efektif terhadap siswa didik. Pada dasarnya bahasa yang digunakan dalam percakapan dipelajari melalui menyimak dan menirukan pembicaraan. Biasanya, anak-anak tidak hanya menirukan pembicaraan yang mereka pahami, tetapi juga hal-hal yang tidak mereka pahami. Kenyataan ini menganjurkan orang tua dan guru menjadi model berbahasa yang baik, supaya anak-anak tidak menirukan pembicaraan yang memalukan atau tidak benar, Mulyati (2008:7.3). Mendengarkan cerita, anak didik akan memiliki kemampuan daya simak imajinatif, kemampuan matematika, dan bahasa. Kemampuan daya simak imajinatif, kemampuan matematika, kemampuan berbahasa merupakan tulang punggung kemajuan peradaban manusia. Dengan ketiga hal tersebut, anak didik dapat mengembangkan teknologi dan kebudayaan.

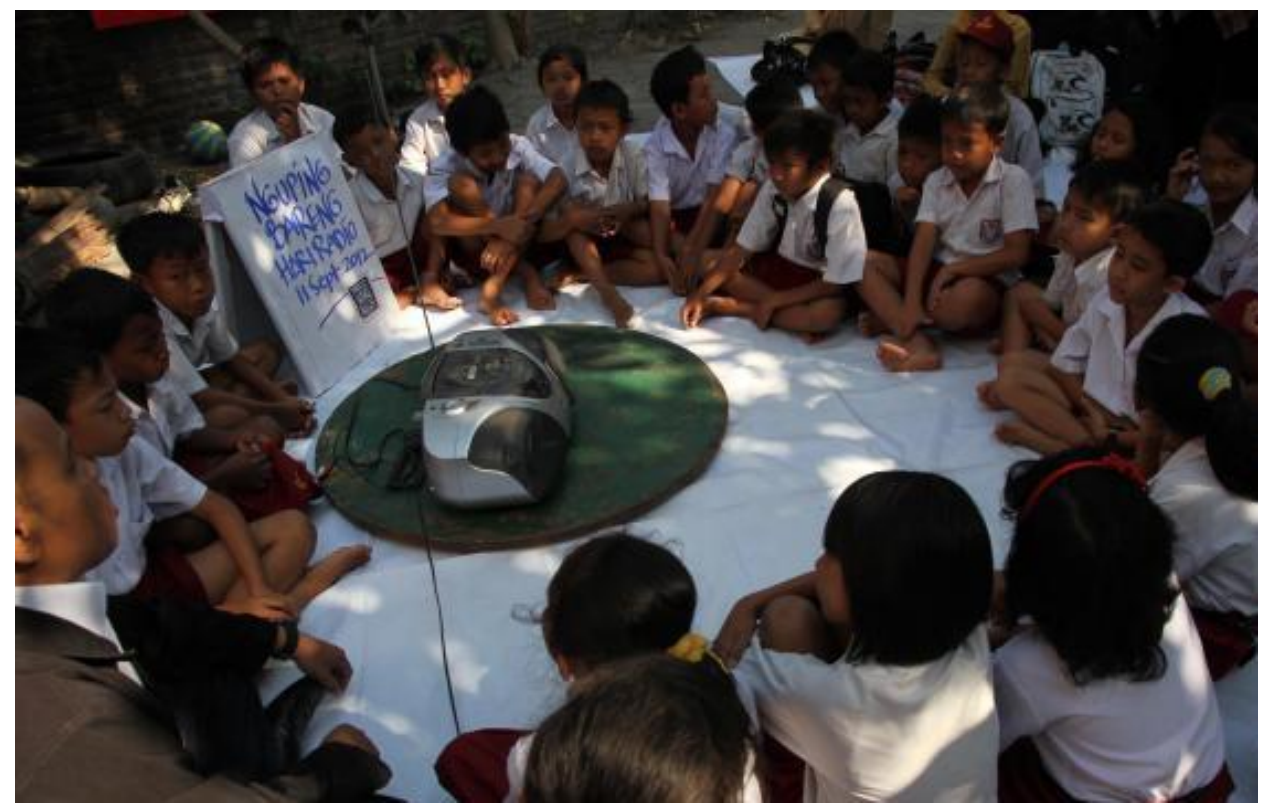

Gambar 2. Kegiatan Menyimak (diambil dari www.google.com) 


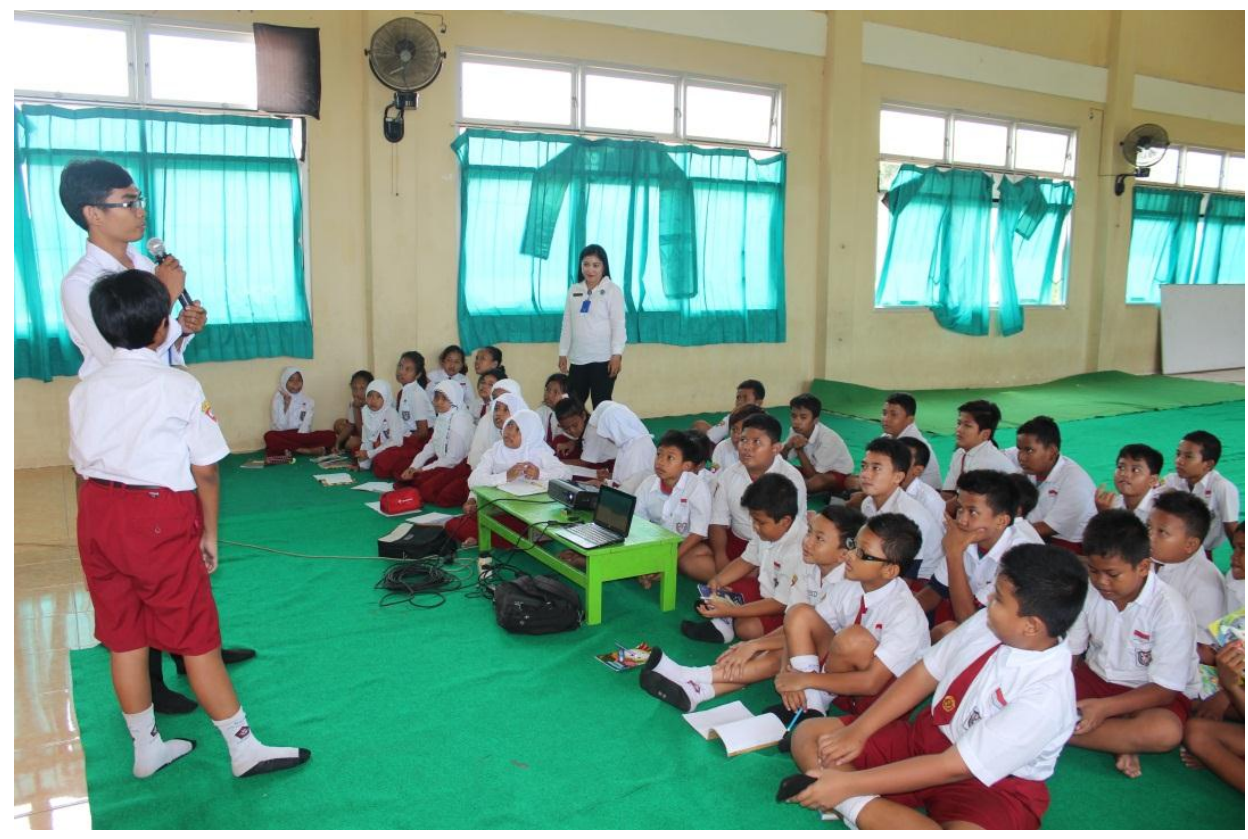

Gambar 3. Berbicara (diambil dari www.google.com)

Bahasa adalah lambang mengenai apa saja yang dapat dijangkau oleh cipta karsa manusia. Kebiasaan mendenngarkan cerita dapat menambah kemampuan berbahasa, selain itu dapat menanamkan budi pekerti. Rene Descret berpendapat bahwa orang yang memiliki daya nalar tinggi dan mampu mengatur pikirannya dengan cara sebaik-baiknya agar jelas dan mudah dimengerti orang lain, selalu mampu meyakinkan orang lain dengan cara berbicara. Dari acuan ini dapat dikatakan bahwa daya nalar yang tinggi terletak pada kemampuan berbicara (menggunakan bahasa). Apabila menyimak cerita dan isi cerita tersebut berkesan, biasanya ada keinginan untuk menceritakan kembali dengan nuansa dan suasana serta cara yang berbeda tanpa mengurangi makna isi cerita tersebut yang diceritakan secara lisan kepada orang lain, Mulyati (2008:7.4)

\section{Langkah pertama}

Menurut Arief (2008) berbicara merupakan proses mengekspresikan, menyatakan dan menyampaikan ide, gagasan serta perasaan dalam bahasa Indonesia dengan mempertimbangkan arah atau tujuan pembicaraan yang berupa proses fisik, sosial, dan mental dengan ciri memberitahukan, menghibur, mengkondisikan, meyakinkan bahkan membujuk/mendesak. Proses menyimak merupakan tindakan menginterprestasikan suatu ujaran/tuturan/wacana dengan cara mengkombinasikan antara yang didengar dan apa yang sudah diketahui baik secara fisik atau mental dengan memfokuskan perhatian, mengarahkan pemahaman untuk melakukan penyimpulan.

Dalam langkah ini, tahap ini, siswa diberikan pemahaman berkaitan makna keterampilan berbicara maupun menyimak, bahwa keterampilan berbicara itu dilakukan dengan menggunakan indra wicara dan menyimak itu pada indera pendengaran. Dengan pemahaman yang jelas atas kegunaan dan makna penggunaan diharapkann siswa akan memahami makna kedua keterampilan tersebut. Pada proses berikutnya, diharapkan pengetahuan itu akan memberikan 
perubahan sikap dan perilaku yang dimunculkan sehingga pemahaman tersebut akan meningkatkan kemampuan daya simak anak didik. Siswa akan berkesempatan pada pola berfikir bahkan memikirkan kebenaran pola sikap tingkah laku terhadap sikapnya selama ini terhadap pemahaman atas kedua keterampilan tersebut.

\section{Langkah kedua.}

Pemantapan atas khasanah pemahaman atas kedua keterampilan pada langkah pertama. Pada proses ini, anak didik diberikan tambahan pemahaman bahwa dalam menyimak tersebut terjadi empat orientasi yang harus diketahui. Orientasi menyimak tersebut adalah reseptif (menerima apa yang sebenarnya dikatakan penutur), konstruktif (merekonstruksikan dan merepresentasikan makna yang disampaikan), kolaboratif (merespon makna yang disampaikan), dan transformatif (membentuk makna selama komunikasi berlangsung dengan melibatkan empati dan imajinasi). Keempat hal tersebut diperjelaskan sebagai pemahaman dengan bahasa yang dapat dipahami dan disesuaikan pada diri anak didik.

Berikutnya anak didik diberikan wawasan bahwa dalam proses menyimak itu terdapat istilah yang dikatakan dengan menyimak interaksional. Anak didik diberikan pemahaman wawasan mendalam perilaku menyimpang dalam menyimak, tujuan menyimak, proses menyimak, hal-hal yang perlu disimak, suasana menyimak, factor-faktor pemengaruh menyimak, factor kenapa menyimak, mengatasi kendala menyimak, dan aneka kegiatan mempertinggi menyimak yang menyatakan suatu proses menggunakan bahasa untuk memenuhi kebutuhan sosialisasi dan berpartisipasi dalam suatu komunikasi. Dan menyimak transaksional yang bermakna penggunaan bahasa untuk memperoleh dan memahami pesan dalam komunikasi. Dalam pantauan selama ini bahwa kelemahan yang maksimal terhadap anak didik adalah ketidaktahuan atas keterampilan berbahasa. Bentuk lain pendidik tidak menjelaskan apa makna dan proses perilaku atas kedua hal tersebut. Dalam tahap ini, anak didik diberikan pemantapan pemahaman tentang makna dongeng dan mendongeng dan fungsi keterkaitan dalam kemampuan menyimak untuk mengembangkan keterampilan daya simak sebagai dasar memahami materi pembelajaran. Siswa berkesempatan untuk memikirkan atau mengingat kembali pengalaman-pengalaman yang mereka sukai untuk mengkaitkan cerita mereka tersebut dengan tema, tokoh, karakter, peristiwa ataupun latar cerita. Lembar kerja diberikan untuk menjawab pertanyaan-pertanyaan yang diberikan.

\section{Langkah ketiga}

Abdul Rani, dkk (2008:16) menegaskan bahwa analisis wacana (dongeng) tidak hanya penting untuk memahami hakikat bahasa, melainkan juga untuk memahami proses belajar bahasa dan perilaku berbahasa yang berkaitan erat dengan pemerolehan kompetensi komunikatif yang hanya dapat diperoleh dalam konteks penggunaan bahasa. Lebih lanjut menurut Ellis menerangkan bahwa analisis wacana percakapan sangat diperlukan untuk mengetahui bagaimana anak-anak memperoleh bahasa. Percakapan (komunikasi dongeng) dapat diamati atas data keseluruhan Dengan mengamati interaksi yang terjadi dalam percakapan. Dari hal ini akan dapat diketahui perilaku dan kompetensi 
anak-anak sehingga pemahaman atas struktur pertukaran, alih tutur, topik dan kohesi koherensi wacana dapat diperoleh yang pada proses lanjut dikembangkan pada kemampuan berbahasa anak, Abdul Rani, dkk (2008:18).

Dalam kegiatan ketiga ini, setelah anak diorganisasikan ke dalam kelompok-kelompok kecil, anak didik diarahkan untuk terlibat secara aktif. Anak diberikan wacana cerita yang sesuai dengan minat dan kesejajaran topik cerita anak. Selanjutnya baik dipilih atau tidak proses keterampilan berbicara dengan fokus menyimak dilaksanakan. Proses berkomunikasi yang bersifat transaksional terjadi dalam lingkup kelas. Pemahaman atas isi komunikasi dipahamkan kepada anak didik. Sehingga terjadi interaksi yang maksimal bervariasi berkaitan tentang topik, tokoh, peristiwa, latar yang dimunculkan atas komponen dongeng yang terbacakan. Anak didik memberikan tanggapan dan pelatihan berbicara yang berupa sumbang sih pendapat atas saran atau tanggapan berdasarkan kemampuan menyimak terhadap dongeng yang dibacakan. Pada proses ini secara bertahap akan terllihat/terungkap peningkatan atas pemahaman konsep yang sudah diperolehnya.

\section{Langkah keempat}

Pada tahap keempat ini anak didik diminta untuk menguraikan apa yang sudah didengarnya ke dalam bentuk wacana tulis dengan pemikirannya sendiri. Bersama kelompok kecilnya merangkumkan kembali isi cerita yang didengarnya berdasarkan fokus yang berupa konsep-konsep dasar pantauan dari tinjauan pendidik atas pembelajaran yang diinginkan. Dan sebelum dipresentasikan atau dibacakan kembali di depan kelas siswa diminta untuk menyunting kembali agar tidak terjadi kesalahan atas penullisannya, untuk menguji kemampuan daya simak yang sudah dilakukan.

\section{Langkah kelima}

Untuk kegiatan selanjutnya, pendidik memberikan LKS dan contoh dongeng. Selanjutnya guru menyampaikan materi secara garis besar dan kompetensi yang diinginkan. Setelah itu guru meminta anak didik untuk memikirkan tema, topik, tokoh, karakter tokohnya, setting, peristiwa atas cerita dongenng yang akan dibacakan sa;lah satu anak didik. Dalam proses ini pendidik memberikan gambaran menyimak yang bersifat atentif, menyimak dengan memfokuskan pada pesan pendongeng, dan menyimak kritis analitis, menyimak dengan berusaha mengevaluasi dan merefleksi pesan pembicara/pendongeng.

Pada tahap ini, tidak pada proses secara berkelompok namun pelaksanaan dilakukan secara mandiri perorangan. Proses ini kali ini untuk mengetahui sampai sejauh mana kemampuan menyimak, daya simak anak didik akan terlihat maksimal secara perorangan. Dengan RPP (Rencana Persiapan Pembelajaran), menyiapkan media yang tepat, penyiapan lembar kerja yang tepat, instrumen (non tes dan tes) yang mendukung, serta penciptaan suasana ynag kondusif menyenangkan dan membangun kepercayaan yang tinggi pada anak didik berpikir kritis serta mampu mengungkapkan ide-idenya, diharapkan kemampuan siswa yang berbeda atas keterampilan berbahasa yang dimiliki akan meningkat. Selanjutnya pendidik akan memberikan pembahasan atas lembar kerja yang berupa tanya jawab singkat kepada seluruh siswa. Pada akhir pelajaran, pendidik

175 BRILLIANT: Jurnal Riset dan Konseptual Volume 2 Nomor 2, Mei 2017 
memberikan bimbingan siswa untuk menyimpulkan materi menyimak secara lisan dan menambahkan hal-hal yang belum diungkapkan siswa dan menyempurnakan.

\section{KESIMPULAN}

Peranan dan tugas guru dalam usaha mengefektifkan pemerolehan bahasa paling tidak mengajukan dan menyediakan tugas atau aktifitas yang memungkinkan siswa terlibat secara aktif berpikir, mendorong dan menyimak dengan hati-hati ide-ide yang dikemukakan secara lisan. Sehingga proses berikutnya anak akan mendapat pemerolehan bahasa yang lebih baik terarah pada pembelajaran yang benar. Dengan metode dengan diikuti suatu teknik yang tepat menyenangkan sesuai dengan keberadaan situasi dan kondisi anak didik yang tepat, sudah barang tentu akan memberikan pemerolehan peningkatan kualitas yang baik bagi anak didik dan otomatis hasil belajar siswa semakin meningkat. Demikian pula dengan keterampilan menyimak yang merupakan kemampuan pertama yang harus dimiliki oleh anak dari keterampilan berbahasanya, akan lebih berhasil dilaksanakan jika diberikan dengan media dongeng yang sesuai dengan anak didik. Sudah barang tentu, pendidik mampu melakukan tindakan kelas dengan proses kebahasaan yang baik dan kondusif, akan memberikan proses interaksi positif anak didik. Dengan story-telling (mendongeng), dapat meningkatkan keterampilan menyimak siswa atau anak didik bahkan akan meningkatkan kemampuan berbicara anak yang dibarengi dengan perubahan karakter yang lebih baik. Dan perlu menjadi sebuah catatan bahwa berbicara (mendongeng) dan mendengarkan (menyimak) merupakan keterampilan berbahasa lisan yang sangat erat kaitannya. Berbicara bersifat produktif, sedangkan menyimak bersifat reseptif. Dalam pemerolehan atau belajar suatu bahasa, keterampilan berbahasa jenis reseptif banyak mendukung pemerolehan bahasa jenis produktif. Dan dalam suatu komunikasi seringkali beberapa jenis keterampilan berbahasa ini secara bersama-sama dipakai untuk mencapai tujuan pembelajaran/komunikasi. Oleh sebab itu, betapa pentingnya keterampilan berbahasa bagi peserta didik dan pendidik dalam pembelajaran.

\section{SARAN}

Dalam pelaksanaan story-telling agar guru dapat merancang pembelajaran yang menarik. Guru dapat memilih cerita-cerita yang menarik. Sehingga penerapan story-telling berlangsung dengan menyenangkan.selain itu, guru juga sedapat mungkin mengatur waktu, agar waktu yang disediakan dapat terpenuhi dengan baik.

\section{DAFTAR RUJUKAN}

Arief, Nur Fajar. 2008. Makalah Hakikat Keterampilan Berbahasa Bahasa Indonesia. Malang.

Busri, Hasan. 2013. Kajian Linguistik Pengantar Memahami Hakikat Bahasa. Malang.

Depdiknas. 2008. Standar Isi untuk Satuan Pendidikan Dasar dan Menengah. Depdiknas. Jakarta.

Dimyati dan Mudjiono. 2009. Belajar dan Pembelajaran. Jakarta: Rineka Cipta. Hamalik, Oemar. 2013. Dasar-Dasar Pengembangan Kurikulum. Bandung: PT Remaja Rosdakarya. 
http:Styasari,Info/2009/04/15:Revitalisasi-Pembelajaran-Bahasa-Indonesia-di Sekolah.Diakses tanggal 21 November 2013.

Mulyati, Yeti. 2008. Keterampilan Berbahasa Indonesia SD. Jakarta: Universitas Terbuka.

Nuraeni. 2010. Keterampilan Berbahasa Indonesia SD. Jakarta: Universitas Terbuka

Rani, Abdul, dkk. 2004. Analisis Wacana sebuah Kajian bahasa dalam Pemakaian. Malang. Bayu media Publishing.

Saryono, Djoko. 2010. Pemerolehan Bahasa Teori Dan Serpih Kajian.Malang: Nasa Media.

UPD, PGSD. 2013. Jurnal Inovasi Pendidikan sekolah Dasar. Kediri: Prodi PGSD UPD Kediri.

www.google.com 